\title{
Looking at the Shared Conception of Teaching Literature in an Indonesian ELT Setting
}

\author{
Sunardi \\ Universitas Mulawarman, Samarinda, Indonesia \\ Mansur Akil \\ Universitas Negeri Makassar, Makassar, Indonesia \\ Burhanuddin Arafah \\ Universitas Hasanuddin, Makassar, Indonesia \\ Kisman Salija \\ Universitas Negeri Makassar, Makassar, Indonesia
}

\begin{abstract}
This paper uses the Interpretative Phenomenological Method to examine the conceptions that English literature teachers (ELITES) share about literature courses and teaching. The study investigated the experiences of four ELITES who taught literature classes at English education base faculties in three universities in Indonesia. These teachers were interviewed and observed in relation to their subject-matter knowledge in literature, their methods of teaching, their roles and the extent of their students' learning. The findings suggest two main themes: (1) ELITES view literature courses as one of the means of learning a language rather than as a "study" in its own right, together with holding a teacher-centered approach; and (2) ELITES' experienced relational conflicts with their students because of the students' perceived deficiencies in understanding literature, their lack of interest in reading and discussing literary works, their lack of motivation to read and appreciate literature, and their deficiencies in English language. Achieving a greater understanding of the experiences of teachers' conception of teaching literature can improve and influence best practice and possibly improve students' learning. The findings of the study have implications for teacher education departments, literacy educators, literary scholars and pre-service educators.
\end{abstract}

Index Terms-teachers' cognition, teaching, conception, literature, English education, interpretative phenomenological analysis

\section{INTRODUCTION}

Research on Indonesian university teachers' professional identity such as their knowledge and beliefs regarding the discipline of teaching literature is scarce. However, the small number of studies that have been done, mainly focusing on teachers' content knowledge within the discipline of literature studies and their attitude towards teaching indicate a similar view about the importance of teacher thinking and beliefs. The present study examines the extent to which professional identity and knowledge profiles identified in previous studies apply to Indonesian teachers of university based education faculties. This article reports on how four English literature teachers (ELITES) from different regions of Indonesia viewed the professional development of their teaching of literature.

This case study outlines the difficulties experienced by early career teachers in teacher education departments when conceptualizing knowledge and learning in the area of literature teaching. The role of the teacher is complicated. In the last few years, numerous writers have identified the characteristics of the complexity of teaching: teachers have to follow different goals and parts at the same time; they have to dominate the content of the subjects taught, from organizing a lesson plan to grading papers; as good as meeting students and managing the personal chronicle of every pupil. Teaching practices differ from many professions because educational practices include a change of actions taking place simultaneously; many positions call for quick action from instructors; many actions take place in the school system; and the effects of many procedures in educational practice cannot easily be predicted (Den Brok, 2001; Doyle, 1986).

One of the most difficult tasks that teachers face is becoming thoroughly familiar with the course content and structure that they are teaching and learning to deliver instruction effectively. If a teacher does not know the materials the students cannot learn. (Thompson, 2002). This implies that teachers have to understand the epistemological discussions underpinning their subject and the need to develop an appropriate pedagogy.

In saying this, the primary intent of the researchers in this study is to grasp the essence of the lived-experience of individual teachers' in literature classes through the use of a different lens, namely that of blended phenomenology and case work. This concept is relatively unexplored in the extant literature in the Indonesian tertiary education context. 
Thus far most studies have focused on the individual teacher and the personal qualities that shape his or her international and teaching patterns in elementary and secondary schools. In the present study, the researcher has shifted the focus to the shared views raised, or commonalities of ideas expressed, rather than the individual aspects and this has led to the application of the Interpretative Phenomenological Approach (IPA) which is based on contemporary practices of literature teaching.

It is interesting to observe that even within the same background of study and workplace, teachers are assumed to possess different approaches to literature and educational activity. In researching the challenges of practice, this study proposes to fill this knowledge gap by examining the growth of early-career teachers with two fundamental research questions:

1) How do ELITES describe their conception, classroom practice and their professional preference with respect to teaching literature (courses) experience?

2) What mediating factors challenge ELITES in teaching their discipline in the faculty-based education?

This work aims to report empirical findings on conceptual content knowledge and pedagogical content knowledge about literature teaching and describe ELITES' efforts to define the subject of literature knowledge for teaching and to refine its sub-domains.

This work is targeted to contribute to teachers, teacher educators and all relevant scholars in Indonesia and other countries sharing similar cultural backgrounds, by providing practical insights about teacher beliefs in teaching praxis. In addition, this work is adding to the body of knowledge base in terms of teacher thinking and exercise from an Indonesian standpoint. (Maulana et al, 2011).

\section{METHODS}

\section{A. Research Design}

This research adopted an interpretative phenomenological analysis (IPA) as a distinctive qualitative approach which places itself firmly in the field of psychology. The IPA rooted in psychology is used as methodology to seek how individuals perceive knowledge and make meaning through their experiences. (Smith \& Osborn, 2008). The mind that ground this premise is that individuals are actively taken in their life-world and are continually reflecting on their experiences to gain understanding. (Smith, et.al, 2009).

The research used this method for two reasons: First, IPA's concern passes into one's own thinking on the field in order to get an insider's view of the phenomenon. Second, IPA attempts to interpret these accounts in order to gain an understanding of and an unravelling of the relationship between what individual teachers think (cognition), say (account for) and do (behavior). Second, IPA practitioners share a commitment to the exploration of personal lived experience.

\section{B. Participants}

The approach to recruiting participants for this IPA study followed from the theoretical account of the epistemology of IPA. This requires that the four participants participating in this study were chosen purposefully. The sample consisted of four English Literature teachers (ELITES) with 5 to 8 years of teaching experience (early-career) in an English Education Department. The four teachers met the further criteria as follows: (1) a non-education disciplinary background; (2) literary studies specialization at the undergraduate level; and (3) employment as early-career teachers in the education based department. The pseudonyms given to the participants are AKAS, PRATIZA, FIRTAS, and HABIB.

\section{Data Collection}

As described above, IPA intends to understand the existential world of the individual participants, leading to the choice of semi-structured, one-to-one interviews consisting of a range of open-ended questions to gather information. Breakwell and Smith (2006) state that the immense majority of IPA studies have been based on data obtained from face-to-face semi-structured interviews and this method of data collection might be considered exemplary for an IPA. (p. $329)$.

The interviews focused on subject-matter cognition, pedagogical approach, teacher self-identity, and how to judge students' learning. In the last phase, the subordinate ideas and sub-topics for the study as a whole were established. Two distinct themes that illustrated the participants' experience and conception of the literature course and the tensions experienced in teaching were identified. The time allotted to the interviews was between 60 and 90 minutes, each interview recorded and transcribed verbatim.

\section{Data Analysis}

The data were analyzed using Interpretative Phenomenological Analysis (IPA). This IPA study adheres to four main stages of the process (Smith, 2009). In the initial phase, the researcher reads the whole transcript to get thoroughly familiar with the information. It is useful to put down some observations and musings around the interview experiences, as well as any other sentiments and remarks regarding the potential significance of the data, in the left margin of the transcript using electronic word review. This is accompanied by a textual analysis that sets out notes and remarks on the transcript. The second stage involves an exploratory commenting. It is an initial noting to examine the content on a very 
exploratory level to transform the initial notes into the emergent themes. In the third stage, a table of themes is produced. The table indicates the picture of major subjects and the sub-topics. An illustrative data extract or quotation is shown alongside each theme, followed by the line number, making it possible to look into the context of the extract.

\section{RESULTS AND DiSCUSSION}

\section{A. ELITES' Conception of Literature and Teaching}

\section{(1) Conception of Literature}

ELITES perceived literature teaching through a lens that combined course characteristics, the relative importance of literature in the curriculum, preferred pedagogical practice and the utilitarian aspect. Data in Table 1 below summarize these conceptions:

TABLE 1

THE ELITES' CONCEPTION OF LITERATURE GAINED FROM THE INTERVIEWS

\begin{tabular}{|c|c|c|}
\hline \multirow[b]{2}{*}{ AKAS } & Nature \& Characteristics of Literature & The Role of Literature in English Education \\
\hline & $\begin{array}{l}\text { - The genres of poetry, prose, and drama that } \\
\text { contain specific values or culture } \\
\text { - A new area for students so they lack } \\
\text { knowledge about it } \\
\text { - It is a source of learning }\end{array}$ & $\begin{array}{l}\text { - Literature course occupies a small place in English Language } \\
\text { education curriculum } \\
\text { - Literature is auxiliary \& peripheral } \\
\text { - Literature is not relevant for student's future career; they want to be } \\
\text { an English teacher, not Literature teacher } \\
\text { - Lit-course as a mean for developing reading skills and appreciation }\end{array}$ \\
\hline PRATIZA & $\begin{array}{l}\text { - Creative reflection of author's real life in } \\
\text { the form of fiction such as poetry, prose, and } \\
\text { drama } \\
\text { - Canonical texts are good to use } \\
\text { - The language of literature is difficult, } \\
\text { especially classics }\end{array}$ & $\begin{array}{l}\text { - Lit-course as a means for developing language, enriching cultural } \\
\text { knowledge, and critical thinking skills; e.g. drama texts support } \\
\text { students' critical analysis and thinking and students' language skills } \\
\text { - Literature should be integrated into the language curriculum } \\
\text { - Students have limited language proficiency to understand literary } \\
\text { texts especially classical texts }\end{array}$ \\
\hline FIRTAS & $\begin{array}{l}\text { - It is about the life and comparison of } \\
\text { people's life, cultural values, and language } \\
\text { - It brings secret things to people } \\
\text { - The literary text consists of intrinsic and } \\
\text { extrinsic elements } \\
\text { - Classical text is okay since it contains the } \\
\text { elevated style of language and culture } \\
\text { - Literature is a barrier the students because } \\
\text { they have limited capacity }\end{array}$ & $\begin{array}{l}\text { - Lit-course as a means for language development \& critical thinking } \\
\text { - A lit - course such as drama can develop students' communicative } \\
\text { skills }\end{array}$ \\
\hline HABIB & $\begin{array}{l}\text { - Literature Should be made familiar to } \\
\text { students } \\
\text { - It is text that is different from other kinds of } \\
\text { texts } \\
\text { - It is a creative art which concerns with } \\
\text { human beings using the artistic expression. } \\
\text { - Literary Text, especially poetry, is different } \\
\text { from other kinds of authentic materials; it is } \\
\text { time consuming to use in the classroom }\end{array}$ & $\begin{array}{l}\text { - Literature is important because it is the sources of learning English } \\
\text { - Literature can support students' four basic English skills } \\
\text { - Lit-course as means for understanding aesthetical values, } \\
\text { developing thinking skills \& generating Knowledge } \\
\text { - Literature in the education department occupies a quite different } \\
\text { focus from the Faculty of Letters (cultural science). }\end{array}$ \\
\hline
\end{tabular}

Information in Table 1 shows a shared conceptualization among ELITES as follows.

(a) The Knowledge of Literature.

In this aspect, ELITES shared a similar view of the nature and characteristics of literature. They took literature to refer to the works created by an author in the different genres - prose, poetry, and drama - that contain special values and cultural knowledge. They acknowledged that teaching students with these understandings of literature were challenging because students bring different degrees of language ability and cultural consciousness. They generally defined literature as a resource rather than a subject field. The ELITES viewed literature as culturally valued text reflecting human life. The ELITES' conceptualizing literature as a text of fiction and non-fiction stories indicated that they concentrate mainly on using literary fiction with a capital " $L$ " in teaching. It is discernible that the literary text used in their teaching is based on the use of prose, verse, drama, and Literature in ELT. McRae (1991) suggests that literature is divided: literature with a capital "L" which refers to the works of prose such as short stories and novels, poetry and drama and so on, as distinguished from literature with a little "l" which includes imaginative texts which can be used as language instruction resources and are not normally studied as literature; for example: advertisements, newspaper headlines, articles, jokes, puns and songs, computer games etc. It is necessary for ELITES to think about both possibilities of literature with a capital and small "l" in language teaching as suggested by Rae above.

The majority of ELITES also perceived Literature as having the potential to assist students to understand language, another culture, and the multiple interpretations that are part of the literary text. Interestingly, the majority of in classroom practices focused mostly on discussing literary aspects such as plotlines, characters, emotional and moral aspects, rather than using those aspects to extend students' language skills such as listening, speaking reading and writing and vocabulary development in classroom practices. Given their contradictions between statement and practice, it is clear that teachers need to see that literature is more than just a textbook; it is a linguistic process, acculturation, and 
knowledge used as a tool for language teaching rather than an end goal. Teaching language through literature, according to (Lazar, 1993, p.2) provides invaluable source of language features and cultural material and values. Literature, encourages language learning, expands students' language awareness and reading abilities, claims which might be related to the role of stylistics in the field of literary texts (Short, 1988; Lazar, 1993; Cook, 1994; Short, 1996).

(b) The Role of Literature.

In this aspect, the placement of literature in English teaching classes was described by the majority of ELITES as occupying a marginalized position. From this perspective, they argued that literature in English Teacher Education Faculties generally received less attention in the language curriculum. In referring to these beliefs, most ELITES advocate that the role of literature in the curriculum should, at best, be served as integrated form with other language courses such as basic English skills because the main purpose of using and teaching literature in English Language Teacher Education (ELTED) is to develop linguistic usage other than values related social and cultural issues.

Another finding that came out from the discussion was the belief that literature is sophisticated, containing difficult language, lack of practicality and is distant from English education students' prior knowledge. Hence, teachers in the field suggested that students need to be familiarized with literature including its specific characters and difficulties. Regarding these features, two of the ELITES (PRATIZA \& FIRTAS) believed that students should be made to engage with canonical texts. However, the other two participants in the study disagreed, maintaining that such engagement is overly hard and requires too much time and moreover, It will not help students to fulfill the curricular objectives around language skills development. Whilst all ELITES acknowledge the particular difficulties for them of using literature as a language teaching resource, they, at the same time, acknowledge that literature has a certain potential in ELT teaching. Literary study as a whole is believed to hold potential in at least three of its strands. First, the literature strand aims to engage students in the study of personal, cultural, societal, and aesthetic values. Literary texts were judged to enrich the lives of students, expanding the scope of their experience because of it represents interesting features and styles. Likewise, it can also develop students' understanding of human experiences. Second, in relation to the language strand, literature may develop students' language features and styles how it is used. These linguistic characteristics enrich the knowledge of the variety of language usage in effective communication. Third, the literacy strand can expand the repertoire of English use, accuracy, and eloquence.

Contrary to expectation, an idea appeared among all ELITES regarding the function of literature (courses) in language education, namely that they all stated that literature should be positioned as sources of learning rather than as the end goal of the study. Unfortunately, none of them in practice treated literary texts as dealing with resources to reveal language use so as to develop students' language skills and vocabulary. As Borg (2003) has also affirmed, what teachers say they do they do not do. This implies that what teacher actually says they do does not entail its occurrence in a schoolroom. It is clear from ELITES' description that they provide literary texts solely in order to interpret the meaning implied.

Another idea arising from the data was that one ELITE, HABIB, avoided using 'Poetry' in teaching since it was time-consuming. In his interview, he stated that his students don't like to read, and don't have enough knowledge of and familiarity with the culture underlying poetic texts. Poetry is usually short but it is a condensed form of work that contains difficult diction. Nevertheless, the majority of ELITES opined that the students tend to be interested in the literature course if they are given texts that pertain to their involvements and to their lives.

They also generally reach consensus that when literature was incorporated, it made joyful learning and activities. The ELITES' views supported Hall's (2005) arguing that literature is that it is supposed to be pleasurable. The four ELITES assured that literature-based activities encourage joyful learning.

A significant insight that is gained from the data in table 1 above is that all ELITES complain that students in their classes struggle with the literary concept and literary aspects. Teachers in this study suggested that students do not possess sufficient understanding of a literary text with respect to terminology, the foreignness of content, and nor do they possess sufficient knowledge and intellect and reading motivation; therefore, they will not help students to meet the same curricular objectives. They also feel that literature's role in the English education curriculum is, at best, integrated, serving as inter-dependent with language to help students acquire basic English skills. In this regard, the ELITES feel the need to be wary about such factors as the learners' language proficiency and background knowledge when choosing texts for students so that they are exposed to certain types of literary texts. This is in line with Vygotsky's (1986) assertion that students will not learn and read beyond their proximal capacities and levels.

(2). Conception of Teaching Literature

The conception of teaching in this field refers to teacher's cognitive dimensions such as prior knowledge, images, beliefs, meanings and self-efficacy attributes concerning the study of literature that may come into play and influence their teaching practices. Findings from the interviews related to these aspects are presented in table 2 below: 
TABLE 2

THE ELITES' CONCEPTION OF TEACHING GAINED FROM THE INTERVIEWS

\begin{tabular}{|c|c|c|c|c|c|c|}
\hline & $\begin{array}{l}\text { Teaching } \\
\text { Literature }\end{array}$ & $\begin{array}{l}\text { Learner's } \\
\text { Interest \& } \\
\text { Attitude }\end{array}$ & $\begin{array}{l}\text { Role of } \\
\text { Teacher }\end{array}$ & $\begin{array}{l}\text { Teaching } \\
\text { Materials }\end{array}$ & Method of Teaching & Goal of Teaching \\
\hline AKAS & $\begin{array}{l}\text { Delivering } \\
\text { knowledge and } \\
\text { skills }\end{array}$ & $\begin{array}{l}\text { Acquiring } \\
\text { knowledge } \\
\text { and skills; } \\
\text { passive } \\
\text { receivers }\end{array}$ & $\begin{array}{l}\text { Deliver and } \\
\text { resource } \\
\text { provider, friend } \\
\text { of students; the } \\
\text { only person } \\
\text { who determines } \\
\text { students } \\
\text { learning }\end{array}$ & $\begin{array}{l}\text { Prefer using short } \\
\text { story for reading } \\
\text { comprehension; } \\
\text { Using films to } \\
\text { motivate students }\end{array}$ & $\begin{array}{l}\text { One-way lecturing plus } \\
\text { focusing on reading and } \\
\text { analysis of literary } \\
\text { aspects; such as } \\
\text { narrative plotline, } \\
\text { character, the point of } \\
\text { view, etc. }\end{array}$ & $\begin{array}{l}\text { - To } \\
\text { - attitude promotion } \\
\text { (appreciation) }\end{array}$ \\
\hline PRATIZA & $\begin{array}{l}\text { Supporting } \\
\text { facilitating } \\
\text { learning and } \\
\text { sharing } \\
\text { information }\end{array}$ & $\begin{array}{l}\text { Depend on } \\
\text { teachers' } \\
\text { and less } \\
\text { creative and } \\
\text { active }\end{array}$ & $\begin{array}{l}\text { Guide, leader } \\
\text { and facilitator } \\
\text { and good model } \\
\text { for students }\end{array}$ & $\begin{array}{l}\text { Follows the } \\
\text { classic materials; } \\
\text { does not meet the } \\
\text { needs of students } \\
\text { and match with } \\
\text { students' level }\end{array}$ & $\begin{array}{l}\text { A variety of methods } \\
\text { emphasises activities } \\
\text { and interaction }\end{array}$ & $\begin{array}{l}\text { Developing understanding } \\
\text { and ability, knowing how } \\
\text { to learn }\end{array}$ \\
\hline FIRTAS & $\begin{array}{l}\text { Teaching as } \\
\text { sharing and } \\
\text { listening to } \\
\text { students' } \\
\text { Changing } \\
\text { students } \\
\text { attitude }\end{array}$ & $\begin{array}{l}\text { Sometime } \\
\text { resistance to } \\
\text { literature } \\
\text { especially } \\
\text { literary } \\
\text { theory }\end{array}$ & $\begin{array}{l}\text { Model of good } \\
\text { learner with } \\
\text { good attitude }\end{array}$ & $\begin{array}{l}\text { Follows the } \\
\text { classic materials }\end{array}$ & $\begin{array}{l}\text { - Knowledge/skill } \\
\text { transfer } \\
\text { - combined classroom } \\
\text { and outbound activities } \\
\text { - Expert-authority in } \\
\text { combined with } \\
\text { attractive-authority }\end{array}$ & $\begin{array}{l}\text { Active and independent in } \\
\text { learning; fostering good } \\
\text { attitude }\end{array}$ \\
\hline HABIB & $\begin{array}{l}\text { Facilitating and } \\
\text { guiding good } \\
\text { conduct }\end{array}$ & $\begin{array}{l}\text { Less } \\
\text { motivated to } \\
\text { read and } \\
\text { resistant do } \\
\text { task }\end{array}$ & $\begin{array}{l}\text { Role model of } \\
\text { good conduct, } \\
\text { friend of } \\
\text { students }\end{array}$ & & $\begin{array}{l}\text { - Knowledge/skills } \\
\text { - Expert-authority; } \\
\text { expert-organizer }\end{array}$ & $\begin{array}{l}\text { - Knowledge delivery } \\
\text { - Ability development } \\
\text { - Language mastery } \\
\text { - Promoting } \\
\text { Attitude(appreciation) } \\
\text { Preparing for exam }\end{array}$ \\
\hline
\end{tabular}

Significant features of the data presented in Table 2 are discussed below.

(a) Teaching Conception in Literature Instruction.

When the ELITES spoke of their English literature class and their experiences of them, almost all believed that students' enjoyment and engagement hinged upon the teacher. The ELITES' conceptions of teaching can be resumed as follows: teaching encourages students to learn; teaching is an educational process directed to change student's conception or apprehension of the world; teaching is facilitating students' understanding; teaching is a transmission of knowledge and attitudes within an academic field of study; and teaching is as telling information.

The profile most frequently mentioned was the teacher who contributed knowledge to students and astounded them with interpretations. The ELITES were inclined to position themselves as the only expert-authority responsible for students' learning and superior knowledge. The method of such a teacher was to begin the schooling the year by plunging herself and the students into an interpretation of every component of the narrative being studied. The ELITE would read a section or an excerpt of the narrative and then explain it to the students. The role of the students was merely to receive her interpretation dutifully and to keep listening. The students were not inclined to speak up in class or to engage in discussion, not because they were reluctant or not motivated to do so, but because of the materials were of no interest to them and too difficult for their level of language ability. PRATIZA typically indicated that the teacher would "go on talking about herself in the classroom." From such a teacher, she indicated students learned the least.

With the profile in mind, all ELITES appeared as only the analyzer of the text rather than as the language instructor. As an analyzer, the ELITE appears as the teacher who does not affect either the culture of students or the students' understanding of textual content in the interpretations or discussions. This teacher would divide the text into its intrinsic literary elements - characters, plot, climax, resolution, narrator, setting, a point of view and so on. This indicated that this type of teacher did not focus on the extrinsic elements such as introducing the author, his ethnicity, and background of the author to connect the writer with what he wrote." Thus, the ELITES felt that their efforts at interpretation proved sometimes faulty because they lacked information on the background of the writer.

The results indicated that all ELITES merely focused teaching on literary aspect for understanding text rather than language educational activities. The students would take the story, respond to some questions and discuss such elements of literature as a plotline, characters, setting, theme and other intrinsic factors. Each week, the students looked for the elements possessed by the text they were reading, for example, short stories, in order to provoke discussion and to write a critical essay. The ELITES also indicated that literature classes that focused on the components of literature did this at the expense of getting meanings from the story. Therefore, students were not involved in the process of constructing meaning or of negotiating it inside the classroom. And as a result, they perceived many of the stories that they took with such a language teacher as pointless and as not related to their culture. Similarly, the students found the task hard because of the particular language features of the texts that were prescribed.

(b) Teacher and Student Roles 
Teachers' beliefs about knowledge influence the way they understand learning and instruction. (Shkedi, 1997). Some ELITES differed in their perspective of cognition. One teacher (AKAS) expressed his ideas about students and knowledge, saying that most of the time he is "the only one who thinks about the target for the students' learning. The students just do it for that day." Others (PRATIZA and HABIB) began to consider themselves as a generator of knowledge (Cochran-Smith, 1994; Marble, 1997). Their position in their classroom was consistently stated as being one in which, as PRATIZA said, she came to regard knowledge as constructed and saw that "in teaching, I too see myself as the facilitator as well as a coach for the students' learning". With this in mind, this ELITE viewed her students as no longer passively receiving knowledge, and her teaching as no longer dispensed expertise. Yet, according to the view held by the majority of ELITES, knowledge is transmitted to students. Indeed, entirely of the ELITES, in this study supported this perspective and talked about knowledge as something that "derives from the teacher, and we know students have memorized it when they can apply or present it." Students absorb the information that the teacher passes on to them. Still, they sounded out one thing that is the opposite of another function. PRATIZA and HABIB, for example, had ever said that teaching is transferring and sharing knowledge and experience to students."

Regarding students' learning, all four ELITES thought that their students were not independent in learning, showed less participation, and were uninterested and unmotivated to learn literature. Several types of 'barrier' can be found in the teachers' reports. First, the barrier of unfamiliar vocabulary. Linguistic communication is, of course, a means of producing communication and closeness, but this is not the situation teachers describe with regard to the words of the literary text. The teachers describe a lack of command of linguistic communication and concept among students. Even, for example, in the contemporary literary text, there is an impression that in all cases of the conflict with the text students perceive the words as strange and wholly difficult to them. Secondly the sentence structure is also a source of difficulty; students learn the literary text sentence structure as peculiar.

Thirdly, there is the roadblock of the foreignness' of content. All ELITES view the strangeness of the texts as a roadblock to learning. The 'foreignness' of the content discourages students to learn, which may easily occur in relation to the cultures of other peoples, but sooner that they create a barrier and even a sense of antipathy. Lastly, at that point is the barrier of knowledge and intellect: for these students, the ideas expressed in the texts are characterized by a lack of explicitness and sometimes by abstractness. This sometimes creates frustration to students. The frustration leads to lack of motivation and of willingness to overcome it. It's difficult for them to comprehend concepts that aren't relevant with their everyday life. These issues that constitute the literary, textual study a task calling for intellectual effort and appropriate readiness. It is no wonder that the four ELITES count these influences among the barriers between the student and the world of the texts. The teachers described a lack of basic knowledge upon which continued learning can be grounded. This includes general background knowledge, basic skills, intertextuality and with basic concepts and literary terms. An additional difficulty is the students' inability to see the textual matter in the context of its own time and the reality of the universe to which it concerns.

As might be expected, some of the aspects that were mentioned in respect to what gets a teacher effective were reiterated in the answers to doubts concerning the characteristics of an effective lesson. There is a trend for all ELITES to emphasize the teacher-led aspects of the literature teaching in the classroom rather than student-centered learning, although they acknowledged that the student-centered aspects are their concerns. It is noteworthy that Watkins (2008) puts forth the notion of learning center-ness and not just learner centeredness.

(c) The Preferred Literary Text Materials for Teaching

As the analysis of data reveals, there are several points that ELITES took into account for selecting literary text for their students: (i) language competency of the students; (ii) the length of the text, (iii) relevance to students' culture or familiar experience; and (iv) students' interest.

(i) Students Language Competency

Most ELITES in this study shared agreement about the use of literary texts based on the students' level of language proficiency because students might feel demotivated if they are not linguistically ready. Nevertheless, some of the ELITES were not uniform in their assertions. At one time, they would report that the language of classic literature is so distant to the linguistic level of the students, but on another occasion say that they used classic texts in their teaching. These practices were related both by PRATIZA and FIRTAS who employed classic dramas in their teaching such as "Pygmalion" by George Bernard Shaw and "Waiting for Godot" by Samuel Becket. These dramas are too long and one of them is a play in the genre of the absurd. Relevant to this, Carter and Long $(1991$, p.5) suggest that it is more truthful to select literary texts which are not too difficult for students to comprehend". It is additionally supported by Hill (1992, p. 142) that literary texts which consist of many unfamiliar of words or expressions discourage the students.

(ii) The length of the text

Considering the length of texts, the data show that not all ELITES agreed to consider Lazar's (1993) mentions that teachers demand to mix in the amount of class time available when choosing literary texts, and that teachers should hold in mind whether they have enough time available to work with texts in class, how long students have to ferment on the text at home (reading) and how much background data about the text, the teacher asks to present scholars. (p. 55). Contrasting findings are presented in this study since PRATIZA and FIRTAS preferred using classic drama in their instructions. Only two ELITES, AKAS, and HABIB appeared to consider literary texts of a more contemporary level. Both these ELITES tended to use short stories in class because the textbook would not absorb so much time to read in 
class. They are also not keen on using poetry, even it is short, because of its difficult language and the time it takes to learn it.

(iii) Cultural Familiarity and Needs

In respect of the themes of literature, ELITES selected texts with regard to teachers' and students' cultural competence. Cultural material that is beyond the students' competence will not incite the students to learn. Hill (1992) mentions that the subject matter of the text should be relevant with the issues or themes which the students' experience. (P. 142). Carter and the Long (1991) share this perspective that the composition of the texts must relate to some extent to culture of the lecturers. (142). For this issue, Lazar (2008) notes that "literary texts which may appear to be really remote in time and place from the Earth today may still hold appeal for students in different nations around the world. This is either because they agree on issues which are relevant to them, or they deal with human relationships and feelings which strike a chord in their' own lives. In this sense, it is an excellent means of inspiring students to read literature whose setting and culture are familiar to them.

(iv) Students' Relevant Interest

All ELITES in the study noted that it is significant to choose texts which can take the kind of personal experience that will arouse the learners' interest. If the students' minds, experiences, and needs are wholly at variance with what they are asked to read, it is useless to expect them to be motivated. One relevant research study points out that if the assigned literary text is meaningful and enjoyable, students will try to overcome the linguistic obstacles enthusiastically (Collie and Slater, 1994: 6-7).

Discussing of this section, the authors would like to quote Carter's and Long's (1991) statements that teachers should select literary texts to which "students can respond and in which they can participate imaginatively, which will construct the reading of literature a memorable, individual and collective experience". (p.3). There is a full variety of literary texts available. Thus, the subject of "difficulty" in regard to literary texts should not be exaggerated. Literature might seem to present special difficulties, but carefully selected, it can be really rewarding.

Considering the reference materials, all four ELITES bring different tastes to choose texts for study. PRATIZA and FIRTAS like to choose canonical classic texts because of their elevated style and higher possibilities of revelation, while AKAS preferring to employ non-canonical texts: "simple short stories are interesting". The latter study was supported by HABIB, who sounded out that not only do short stories have manageable length but also contain exciting characters and yet simple plots that make them more accessible to the students. Although HABIB considered poetry is shorter than most of the other genres of literature, but its structural and linguistic complexity, especially the particular use of vocabulary, would be overly problematic for his students. HABIB's experience told us that the widespread reasons for many other ESL educators who hesitate about the purpose of poetry in their teaching. Teaching poetry is hard to understand because of its symbolic words and its metaphorical expressions" (see Lazar 1994; Short 1996a). PRATIZA also felt less eager about the use of poetry into teaching. She attributed her disinclination to her experience of struggling to find poems with relevant topics or ideas, maintaining that appropriate themes were easily available and plentiful in other types of literary text.

\section{(d) Teaching Method}

The findings regarding the ELITES' teaching methods showed that most ELITES' views are still firmly rooted in the traditional view of knowledge. Their practice has not substantially confirmed their acceptance of a reformed approach to teaching since all of them still view themselves as "monopolizing" and "selling" knowledge. For example, each of these ELITES still recognizes teaching as 'telling' in one hand and 'receiving' in another hand. They are inclined to position themselves as expert and teller of knowledge from one person to another. This conception of teaching drives their teacher decision making down traditional method or teacher-centered pathways. In addition to the roles the ELITES play, it could be assumed that the majority of the ELITES place themselves as expert-authority and students as the passive recipient of knowledge. These conceptions were reflected in their comments that: "students lacked prior knowledge about literature; the literature was so distant to them, and literature has a spectacular style and difficult use of language; the role of literature in the language curriculum was so limited". The accounts implied that teaching and learning in literature course should be conducted in an integrated manner; language and literature should receive balanced attention in the language education curriculum. Through the habit of this model, students may become more aware of familiar grammar, vocabulary or patterns of discourse that may be practiced effectively in several genres and may uncover them to the formal rules of written speech.

Further, ELITES' comments on defining teaching as instructing, transferring, sharing and informing knowledge to students demonstrated that they understood their role as being that of knowledge transmitter. This view was generally acknowledged that the interaction between teachers and students in the classroom was very one-sided. Teaching manifested in classroom practices placed students as only absorber information from teacher rather than they actively generate their own knowledge and learning process. In observing those ELITES' classroom teaching practices, the researcher argued that most ELITES are still persistence on the transmissive approach to teaching where knowledge is generated by lecturers.

However, some inconsistency appeared in the instructions made by a majority of the ELITES involved in this inquiry. This was supported by data obtained from the interviews showing different or even contradictory opinions about conceptions of teaching. When one of the ELITES, PRATIZA, was asked her conception about teaching, she 
acknowledges that teaching is a process 'to deliver knowledge as well as methods and skills', but when requested to response about her role as teacher, she answered that she was a model/ tutor's role in assisting student learning' (PRATIZA). The former answer reflected clearly a molding orientation while the latter implied a cultivating orientation. It implied that a lecturer's stated conception is in unalignment or in contrast with his or her classroom practice. There is no one-to-one correspondence between stated conception and classroom practice. A lecturer may have one strong belief but in the classroom practice, a lecturer might apply different and sometimes contradictory practice. Considering this case, authors argue for the importance of considering academics' underlying intentions in approaching their own development as a teacher, and not only the developmental methods and strategies they engage in. Teaching development involves more than content, methods, and consequences; being a teacher requires continuing development of how to teach students a lesson.

(e) Teaching Goals.

The goals of teaching that emerged from the ELITES' data can be broken down into knowledge delivery, ability development, attitude promotion and conduct guidance, and exam planning. This research is similar to what Gao and Watkins (2002: 66-68) discovered in China, namely that teaching is described as content knowledge development, ability improvement, attitude promotion, and cultivation and preparation for the exam. At the degree of pedagogical awareness, each teacher articulated a clear vision of his goals for his students. Yet, he proceeds to articulate the pedagogical significance of literature in terms of a linguistic resource such as increased writing ability and cultural enrichment for the student.

\section{B. ELITES' Challenges in Teaching Literature Course}

The results of the interviews with ELITES are summarized in table 3. The following sample responses may give a clear indication of ELITES' feelings of tension between teachers' beliefs about literature and classroom-context factors: student ability in literature, student attitude towards literature, classroom management.

TABLE 3

FACTORS SHAPING ELITES' CHALLENGES IN TEACHING LITERATURE COURSE

\begin{tabular}{|c|c|c|c|c|}
\hline \multirow[t]{2}{*}{ Themes } & \multicolumn{4}{|l|}{ ELITES } \\
\hline & AKAS & PRATIZA & FIRTAS & HABIB \\
\hline $\begin{array}{l}\text { Students' limited } \\
\text { language skills and } \\
\text { interest in reading }\end{array}$ & $\begin{array}{l}\text { - low ability in reading } \\
\text { complicated text such as } \\
\text { novel } \\
\text { - receiving information } \\
\text { \& knowledge from each } \\
\text { other }\end{array}$ & $\begin{array}{l}\text { - low-level English } \\
\text { proficiency } \\
\text { - low reading interest in the } \\
\text { long text such as novel } \\
\text { - dependent; would be } \\
\text { active in the created } \\
\text { situation }\end{array}$ & $\begin{array}{l}\text { - less active and not } \\
\text { enthusiastic, some } \\
\text { could be motivated }\end{array}$ & $\begin{array}{l}\text { - resistance to reading } \\
\text { assignments especially long } \\
\text { text, novel } \\
\text { - dependent on teacher's } \\
\text { direction }\end{array}$ \\
\hline $\begin{array}{l}\text { Limited knowledge } \\
\text { of literature }\end{array}$ & $\begin{array}{l}\text { - lack of prior knowledge } \\
\text { of literature }\end{array}$ & $\begin{array}{l}\text { - lack of literature } \\
\text { knowledge }\end{array}$ & $\begin{array}{l}\text { - lack of knowledge } \\
\text { and not understand } \\
\text { literature }\end{array}$ & $\begin{array}{l}\text { - unfamiliar with the } \\
\text { literature } \\
\text { - students are not able to } \\
\text { organize learning. }\end{array}$ \\
\hline $\begin{array}{l}\text { Classroom } \\
\text { management }\end{array}$ & $\begin{array}{l}\text { - passive \& unresponsive } \\
\text { - low motivation }\end{array}$ & $\begin{array}{l}\text { - passive \& lazy to practice } \\
\text { - resistance sometimes to a } \\
\text { part of the literary materials } \\
\text { or topics } \\
\text { - happy with practical } \\
\text { materials rather than theory }\end{array}$ & $\begin{array}{l}\text { - resistance to } \\
\text { materials which are } \\
\text { related to the theory } \\
\text { - prefer practical } \\
\text { materials rather than } \\
\text { theory }\end{array}$ & $\begin{array}{l}\text { - resistance to reading tasks, } \\
\text { low ability and attitude } \\
\text { towards literature }\end{array}$ \\
\hline
\end{tabular}

\section{(1) Teaching Literature to Weak Students}

The majority of ELITES explicitly expressed that the biggest challenge was to teach weak students about literature, saying that students just wouldn't read the literary text no matter how much time they gave them. For students, it is really hard to discuss story (plot, themes, characters, etc) when they know nothing about the story. The ELITES further commented that a lesson would not be successful until the teacher presented them with a simple narrative and then attempted to elicit simple answers from students (AKAS and PRATIZA). Further, ELITES said weak students did not like literature if it contains difficult words to spell and to read. As a text for study, poetry presents a problem for weak students. The sentences do not make sense when the meaning of the individual words is not known. For such students, ELITES employ strategies such as selecting materials for students that do not exceed their ability to grasp the meaning. To sum up, language is a challenge for the weaker students that require teachers to resort to particular techniques. Teachers have come to terms with the fact that they cannot make all students react to the literary text word for word and understand it but they can make them interpret the storyline using their own techniques.

(2) Students Lacking Interest in Literature Activities and Discussion

The second language literature classroom as described by ELITES as characterized by marked learner passivity. In FIRTAS's and PRATIZA's classes, for instance, the better students were not really interested in carrying out activities and discussions involving the novel or poetry but would from time to time ask about the possible questions to be asked in the examination. It is in fact very difficult to maintain their interest in 'learning' or studying literature in the classroom. This situation is supported by HABIB when he reported that sometimes he would be baffled by the students' lack of interest and the lessons would end up in lots of punishments and force. In summary, students were too exam- 
oriented and would really panic and get upset when they were not instructed to resolve certain queries. Often times, they 'haunted' their teachers to give them clues on the exam questions and would go all out to memorize model answers just for making good grades in the literature class.

\section{(3) Less Motivation to Read and Appreciate}

It is always challenging for all ELITES to arouse students' interest in reading, especially novels. They noted that students do not appreciate literary pieces as much as the ELITES themselves used to in those good old days when they were students. They also observe that students these days do not read much literature on their own either, outside those allotted them for study. Possibly, this is due to the ever-advancing information technology where students are exposed to more social websites and entertainment sites such as Facebook, myspace, online games, etc. in comparison with which they may find reading literature boring. As a teacher, he or she must be aware and must anticipate these shifting trends in students' style of learning and needs. He or she must be quick to confront the students who do not read the literary pieces assigned to them. (http://harass.standfor.edu). As HABIB has reported, he remembered experiencing bad mood and feelings of anger when he found students refusing to do presentations or not completing hoework or other assigned tasks. Teaching appreciation of literature and teaching for examination are two dissimilar things. The fact is, examination sets the direction of the teaching and learning in the educational setting explored in this study, and students and teachers realize this. However well-meaning the teachers, literature cannot be 'appreciated' to its fullest if it is applied as a tool to evaluate students through testing.

(4) Students' Deficient in Language

Basically, the challenges faced when teaching literature was similar amongst all the teachers in this study. As the ELITES reported, they actually have a problem with language as most students were not able to engage with literary pieces because they are not advanced enough in linguistic levels. Two ELITES (HABIB and PRATIZA) have observed situations where students have trouble to understand poems. This is due to the stylistic features such as figurative languages such as symbols and metaphors. HABIB, therefore, does not want to use poems to teach in his classroom because it is time-consuming. Other factors that might make it difficult for students to learn literary pieces such as poetry include the student's limited vocabulary in English and lack of background knowledge of the culture in the story. These facts halted the effective teaching of poetry and other pieces of literature.

\section{CONCLUSION}

The predominant insights that can be drawn from the data gathered for this study include the following:

(1) All ELITES draw on some aspects of the views, approaches, and emphases concerning the ways in which literature is conceptualized in ELT. In the dimension of subject-matter knowledge, Literature is viewed by most ELITES in terms of three main strands: literature, language, and literacy. In the literature strand, teachers consider that students can engage in the study of the literary text in regard to personal, cultural, societal and aesthetic and creative values. The literary text was judged to possess the potential for enriching the lives of students, amplifying the range of their experience, and representing interesting cultural ideas. It is likewise perceived that literature creates an opportunity for students to appreciate and to create their own literary text, enriching their understanding of human experiences and the capacity for interpretative skills to achieve literary understanding. In the language strand, ELITES considered that literature can develop students' English language usages and styles; they learn how language enables people to interact effectively. It builds students' knowledge about how language can be used for aesthetic ends; students interpret, appreciate, evaluate and create literary texts such as short stories, novels, and drama. For the literacy strand, literature is viewed as sources of expanding the repertory of English usage and as a medium to develop abilities to interpret and create text with appropriate accuracy and fluency. Other than potential strands, insights emerged from ELITES regarding Literature was that Literature was sophisticated, containing difficult language, lack of practicality and distant from English education students' prior knowledge. Consequently, it will not help all students to meet the same curricular objectives. In addition, teachers in the study feel that literature in the English education curriculum is, at best, not peripheral, serving not as an independent course but as an integrated one;

(2) ELITES' challenges and relational conflicts related to teaching literature courses stemmed from multiple sources such as students unfamiliar with the study of literature, students uninterested in literature-teaching activities and discussion, students with low motivation to read and appreciate literature, and students deficient in language. While ELITES complain that students in their classes are faced with difficult literary texts and, therefore, with difficulty learning the presented literary concepts, ELITES nevertheless assumed that literature is however potential for engaging students to literary concepts and aspects through texts that are written at an appropriate reading and language level of proficiency. Going along to pick out traditional canonical texts that pose several obstacles to students of the "microwave generation", that are irrelevant to the students' lives and interest, and require a teacher's aid to decipher meaning, will constrain the time available for truly teaching literature in the schoolroom. Encouraging students to study literature increased literacy skills, which in turn it requires teachers challenge and re-imagines some of their traditional approaches to literature teaching.

The findings of this study support the utilization of literature in the English Language Education curriculum has already put forward. Literature offers teachers reasonable options for teaching language because it (a) contains literary devices and interesting linguistic styles that attract students' interest; (b) develops language skills through extension 
activities with appropriate literary works; (c) provides a bridge for reluctant and struggling readers to successfully read classic works of literature; and (d) builds literacy skills in students.

\section{ACKNOWLEDGEMENTS}

The authors wish to thank Dr. Derek Wallace for his significant roles in reading, reviewing and checking the language of this paper. A grateful thank also goes to the director of PPS UNM, the head Program, Prof. Haryanto for the academic support facilitation and Prof. Amir Masruhim, for support in part by a grant.

\section{REFERENCES}

[1] Akerlind, Gerlese. (2004). Ä new dimension to understanding university teaching”, Teaching in Higher Education.

[2] Breakwell, Glynis M, and Smith, Jonathan. A. (2006). Research Methods in Psychology. London: SAGE Publication

[3] Borg, S. (1999). Studying teacher cognition in second language grammar teaching. Elsevier Science Ltd., System, $27,19-31$.

[4] Borg, Simon. (2006). Teacher cognition and language education. Research and P ractice. London: Continuum.

[5] Bowden, John A \& Eleanor Walsh. (2000). Phenomenography. Australia: RMIT Publishing

[6] Carter, R \& Long, M. (1991). Teaching Literature. Oxford: Oxford University Press.

[7] Carter, R. \& McRae, J. (eds) (1996). Language, Literature and the Learner. Harlow: Addison Wesley Longman.

[8] Carter, R. \& Nash, W. (1990) Seeing through Language. Oxford: Blackwell.

[9] Carter, M., \& Long, M. (1991). Teaching Literature. Essex: Longman.

[10] Christenbury, L. (2000). "The guy who wrote this poem seems to have the same feelings as you have": Reader-response methodology. In N. J. Karolides (Ed.), Reader response: In secondary and college classrooms (pp. 47-61). Mahwah, NJ: Lawrence Erlbaum.

[11] Cochran-Smith, M. (1994). Cochran-Smith, M., \& Lytle, S.L. (1999). Relationship of knowledge and practice: Teacher learning in Community. In the series, Review of research in Education, 24, 249-305. Washington, DC: American Educational Research Association.

[12] Collie, J. \& Slater, S. (1987). Literature in the language classroom: a resource book of ideas and activities. New York: Cambridge University Press.

[13] Cook, G. (1994) Discourse and Literature. Oxford: Oxford University Press.

[14] Cuban, L. (1993). How teachers taught: Constancy and change in American classrooms, 1890-1990 (2nd ed.). New York, NY: Teachers College Press.

[15] Den Brok, P.J. (2001). Teaching and student outcomes: A study on teachers' thoughts and actions from an interpersonal and a learning activities perspective. Utrecht: W.C.C.

[16] Doyle, W. (1986). Classroom Management and Organization in M.C. Wittroch, Handbook of Research on Teaching, No.5

[17] Gage, N. L. (2009). A conception of teaching. New York, NY: Springer-Verlag

[18] Renshaw, T. T. (2013). How To Enable Asian Teachers To Empower Students To Adopt Student-Centred Learning. Australian Journal Teacher Education, 38(11). 65-85

[19] Gao and Watkin. (2002). Conceptions of teaching held by school science teachers in P.R. China: identification and crosscultural comparisons International Journal of Science Education. Vol. 24, NO. 1, 61- 79. Taylor and Francis.

[20] Gao, Lingbiao. (2002). "Conceptions of Teaching held by school science teachers in P.R. China: Identification and crosscultural comparisons", International Journal of Science Education.

[21] Hall, E.T. (1966). The hidden dimension. New York: Doubleday

[22] Hall, G. (2005). Literature in Language Education. New York: Palgrave

[23] Jago, Carol. (2000). With Rigor for All: Teaching Classics to Contemporary Students. Portland, ME: Calendar Islands.

[24] Kickerbocker, I.L., \& Rycik. (2002). "Growing into Literature: Adolescents' Literary Interpretation and Appreciation,” Journal of Adolescent and Adult Literacy 46.3; 196-208.

[25] Lafferty, George. (1996). "A question of resources: Higher education research, teaching social science and the academic labor process in Australia. The Australian Educational Researcher.

[26] Lazar, G. (1993). Literature and language teaching: A guide for teachers and trainers. New York: Cambridge University Press.

[27] Lazar, G. (2008). Literature and Language Teaching. 16th Printing. Cambridge: Cambridge University Press.

[28] Maley, A. 1989. Down from the pedestal: literature as a resource. In Brumfit, C.J. \& Carter, R.A. (Eds.), Literature and the Learner: Methodological Approaches (pp. 10-23). London: McMillan

[29] Maley, A \& Duff, A. (1989). The inward ear: poetry in the language classroom. Cambridge: Cambridge University Press.

[30] Marble, S. (1997). Narrative Vision of Schooling. Teaching and Teacher Education, 13 55-64.

[31] Marble, S. (2000). Understanding teachers' perspectives on teaching and learning. Advance Research Improving Education. SEDL. Austin, Texas

[32] McRae, J. (1991). Literature with a Small '1'. London, Macmillan/Prentice Hall.

[33] Moustakas, C (1994). Phenomenological research methods. London, Sage

[34] Maulana et al. (2011). Teacher-student interpersonal in Indonesia: profiles and importance to student motivation. Asia Pacific Journal of Education. Vol 31, 2011-issue 1

[35] Rosenblatt, Louis, M. (1991). Literature as Exploration, $4^{\text {th }}$.Ed. New York: Modern Language Association of America.

[36] Samuelowicz, K., \& Bain, J. D. (1992). The conception of Teaching held by the academic teacher. Higher Education, 2, 93-111

[37] Shang, H. (2006). Content-based Instruction in the EFL Literature Curriculum. The Internet TESL Journal, Vol. XII, No. 11.http://iteslj.org/Techniques/Shang-CBI.html (accessed 26/3/2014).

[38] Short, M. (ed.) (1989). Reading, Analysing and Teaching Literature. Harlow: Longman.

[39] Short, M. (1996). Exploring the Language of Poems, Plays, and Prose. London: Longman. 
[40] Short, M. H. \& Candlin, C. N. (1986). Teaching study skills for English literature. In C. J. Brumfit \& R.A. Carter (eds) Literature and Language Teaching. 89-109. Oxford: Oxford University Press.

[41] Shulman, L. S. (1998). Theory, practice, and the education of professionals. The Elementary School Journal, 98(5), 511-526. N. Entwistle, D. S. (2000). Conceptions and beliefs about "good teaching": An integration of contrasting research areas Higher Education Research \& Development. (18), 5-26.

[42] Shkedi, Asher. (1997). The Tension between 'óught' and 'is; teachers' conceptions of the encounter between students and culturally valued texts.

[43] Smith, Jonathan A., Paul Flowers \& Michael Larkin. (2009). Interpretative Phenomenological Analysis. Theory, Method, and Research. London: SAGE Publication Ltd.

[44] Smith, J.A., Flowers, P. \& Larkin, M. (2009). Interpretative Phenomenological Analysis: Theory, Method, and Research. London: Sage

[45] Smith, J.A., Flowers, P. and Osborn, M. (2003). 'Interpretative phenomenological analysis and health psychology', in Yardley, L. (ed). Material Discourse an Health (pp. 68-91). London: Routledge.

[46] Thompson, P. W. (2002). Didactic objects and didactic models in radical constructivism. In K. Gravemeijer, R. Leherer, B. VanOers \& L. Verschaffel (Eds.), Symbolizing, modeling, and tool use in mathematics education. Dordrecht, The Netherlands: Kluwer

[47] Vygotzky, L.S., (1986). Though and Language. Cambridge, MA: The MIT Press.

[48] Watkins, D. A., and Biggs, J. B. (2001). Teaching the Chinese learner: Psychological and pedagogical perspectives. The University of Hong Kong, Hong Kong: Comparative Education Research Centre and Australian Council of Educational Research.

[49] Watkins, L. G. (2008). Conceptions of teaching held by school science teachers in P.R. China: identification and cross- cultural comparison

[50] Yigit, N. (2013). The latest reform in initial teacher education (ITE) in Turkey. Energy Education Science and Technology Part B. Social and Educational Studies, 4(1), 523- 536. Retrieved from http://www.silascience.com/articles/16122012004414.pdf. (accessed 3/7/ 2016).

[51] Zhu, Zhiyong and Xiaohui Fan. (2012). "Reflections on Teachers' Conception of Teaching: A Case Study", Chinese Education \& Society.

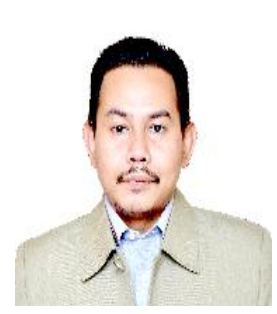

Sunardi was born on 6 June 1971 in Tanahberu, Bulukumba, South Sulawesi. He earned his first degree in 1995 in English and Literature at the Faculty of Letters (now called as the Cultural Science faculty) at Hasanuddin University, Makassar Indonesia. The second degree was pursued at English language studies in 2000 at Postgraduate Program of Hasanuddin University, Makassar, Indonesia. He has been employed as English literature teacher at English Education department at Mulawarman University since 2002 up to the present. He also holds a position as Secretary of Masters of English Education Program at Mulawarman University since 2010 until now. Currently he interested in the research related to English Literature and its application to the Teaching of English and literacy. Sunardi, S.S., M.Hum is one of the members of ASIA-Tefl since 2013. Email: sunardi.osu2016@ gmail.com.

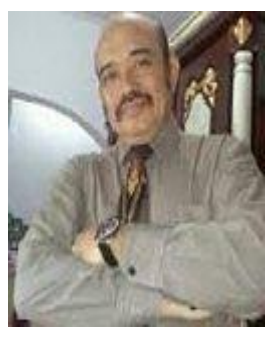

Mansur Akil (Prof. Dr.) was born in Biru, Bone, 17 June 1959. He earned his S1 degree in IKIP Ujungpandang and S2 Degree in UPI Bandung. He continued to get his doctorate level in the English Language Studies in UNHAS, 2007. He is Professor in Translation. His research interest is in translation, multicultural education and Curriculum development. He is a senior lecturer at undergraduate and postgraduate studies in the Philosophy of Science, Psycholinguistics and Theory Construction.

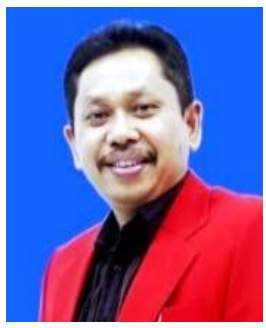

Burhanuddin Arafah, (Prof. M.Hum., Ph.D.) was born Cangadi, Soppeng, 3 March 1965. He got his professor 2014. His bachelor degree was in English Literature Hasanuddin University, 1988. He earned his master degree in Universitas Gadjah Mada in American Studies, 1995. His doctorate degree in English Literature was in 2004 at the University of Newcastle, Australia. He is a senior lecturer and he is now teaching English Literature courses and Discourse at undergraduate and graduate level at English Literature and Linguistic Department UNHAS. His research interest is in English literature.

Email: burhan-arafah@unhas.ac.id. 


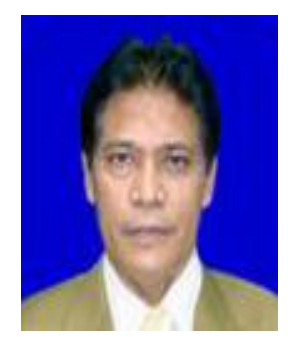

Kisman Salija, M. Pd. is a senior lecturer at the English Department. He has been teaching English at UNM since 1980. He is now teaching Academic and Creative Writing Courses at undergraduate and graduate level at English Department UNM., Indonesia. His research interests are in the Teaching of Academic and Creative Writing by Indonesian young Learners English, and Language Testing. Email: kismansalija@gmail.com / kisman.salija@unm.ac.id. 